\title{
EVALUACIÓN (CON PERSPECTIVA DE GÉNERO) DEL PROGRAMA DE IGUALDAD DE LA SEMARNAT 2013 EN MÉXICO
}

\author{
EVALUATION (WITH GENDER PERSPECTIVE) OF THE SEMARNAT \\ EQUALITY PROGRAM 2013 IN MÉXICO
}

\author{
B. Gilliana Alcaraz-Vargas ${ }^{1}$, M. Aidé Núńez-Vera ${ }^{2}$, J. Antonio Hernández-Moreno ${ }^{3}$
}

\begin{abstract}
${ }^{1}$ Centro Regional Centro Occidente, Universidad Autónoma Chapingo. Reforma No. 11, Tulantongo, Texcoco, Estado de México.56217. (alcarazbg@gmail.com). ${ }^{2}$ Centro Regional Centro Occidente, Universidad Autónoma Chapingo. Periférico paseo de la república No. 1000, Col. Lomas del Valle, Morelia Michoacán. 58000. (miri_nuve@yahoo.com.mx). ${ }^{3}$ Ciencias Forestales, Colegio de Posgraduados Campus Montecillo. Carretera México-Texcoco Km 36.5, Montecillo, Texcoco, Estado de México. 56230. (tecnobiosfera@gmail.com)
\end{abstract}

\section{Resumen $\quad$ Abstract}

Las políticas públicas para mujeres en México se centran en la inclusión de la perspectiva de género en los programas y proyectos gubernamentales que promueven el desarrollo. Su estrategia es la transversalización de la equidad de género. Una de las instituciones de gobierno que tiene este mandato es la Secretaría de Medio Ambiente y Recursos Naturales, mediante el programa de Igualdad de Género y Sustentabilidad Ambiental. El presente trabajo aborda un análisis del nivel de incorporación de esta perspectiva en el diseño, operación y ejecución del programa de referencia, mediante la implementación de una metodología de verificación de género para programas sociales. La política de Igualdad de Género en el sector medio ambiente se enfoca en las necesidades prácticas de las mujeres, por lo que atiende las actividades para el sustento familiar; es una estrategia que requiere integrarlas en el proceso de planeación y aplicación de la política pública, con el apoyo de los diferentes actores sociales.

Palabras clave: medio ambiente, políticas públicas, transversalidad.

\section{INTRODUCCIÓN}

$\mathrm{E}$ 1 debate sobre mujer y medio ambiente comenzó a incluirse en la agenda política durante los ańos noventa del siglo XX, como tarea para todos los gobiernos del mundo, emanada de cumbres internacionales. El acelerado proceso de degradación ambiental impulsó la necesidad de analizar

* Autor responsable * Author for correspondence.

Recibido: septiembre, 2014. Aprobado: diciembre, 2015.

Publicado como ARTÍCULO en ASyD 13: 303-324. 2016.
Public policies for women in México are centered on the inclusion of the gender perspective in the government programs and projects that promote development. Their strategy is the mainstreaming of gender equality. One of the government institutions that have this mandate is the Secretaría de Medio Ambiente y Recursos Naturales, through the Gender Equality and Environmental Sustainability program. This study approaches the analysis of the level of incorporation of this perspective in the design, operation and execution of the program of reference, through the implementation of a methodology of gender verification for social programs. The policy of Gender Equality in the environmental sector is focused on the practical needs of women, which is why it addresses the activities for family sustenance; it is a strategy that requires integrating them into the process of planning and implementation of the public policy, with the support of different social actors.

Key words: environment, public policies, mainstreaming.

\section{INTRODUCTION}

T The debate about women and the environment began to be included in the policy agenda during the 1990s, as a task for all governments of the world, resulting from international summits. The accelerated process of environmental degradation drove the need to analyze the current impact that the economic model generates in women and men in a differentiated manner. This discussion is sustained on a debate that began globally in the 1970s, with the demand of including the category of gender in 
el impacto actual que genera de manera diferenciada el modelo económico en mujeres y hombres. Esta discusión se sustenta en un debate que a nivel mundial se inicia en los ańos setenta, con la demanda de incluir la categoría de género en el análisis público. Hasta entonces la diferencia sexual no era abordada como una forma de comprender la realidad, y el sexo se consideraba únicamente como una categoría descriptiva de la población (Incháustegui, 2012). A partir de la presión social que representó el movimiento feminista a nivel mundial y a los estudios que se basan en el análisis de la organización social de la diferencia sexual, se describe y reconoce una nueva forma de desigualdad social.

La categoría género ha tenido el objetivo de contribuir a mejorar la equidad entre mujeres y hombres e impulsar su ciudadanía plena. Esta iniciativa demanda un enfoque integrado por poderosos componentes político-institucionales que reviertan la distorsionada distribución de oportunidades por género. Hombres y mujeres tienen condiciones, situaciones y necesidades diferentes, que deben considerarse y reflejarse en las políticas públicas (Incháustegui, 1999).

En este sentido las políticas públicas deben considerar la inclusión del enfoque de género en todos aquellos programas de gobierno que promueven el desarrollo humano. A esta estrategia se le conoce como Transversalidad ${ }^{4}$ de género. Una de las dependencias de gobierno en México que tienen este mandato es la Secretaría de Medio Ambiente y Recursos Naturales (SEMARNAT), mediante el programa de Igualdad de Género y Sustentabilidad Ambiental. Su principal objetivo es: "Institucionalizar la perspectiva de género en las políticas públicas de la Secretaría y de sus órganos sectorizados, y asegurar la transversalidad de la misma en el marco de sus atribuciones, a fin de garantizar el adelanto de las mujeres y la igualdad de género en cada uno de los ámbitos y retos de la agenda ambiental" (SEMARNAT, 2008).

Según Ruiz y López (2003), el surgimiento de esta iniciativa comienza en México en 1998 con la participación de la Secretaría de Medio Ambiente, Recursos Naturales y Pesca (SEMARNAP), la Comisión Nacional de la Mujer (CONMUJER) y la Red Mujer y Medio Ambiente, quienes fueron un detonador que delineó los pasos a seguir para la adopción del enfoque de género en las políticas públicas ambientales en México. Posteriormente se concretó, entre otras cosas: La Declaración para la Equidad de public analysis. Until then, sexual difference was not addressed as a way to understand reality, and sex was considered solely as a descriptive category of the population (Incháustegui, 2012). Stemming from the social pressure that the feminist movement represented at the global level and the studies that are based on the analysis of the social organization of sexual difference, a new form of social inequality is described and recognized.

The gender category has had the objective of contributing to improve the equity between women and men and of promoting their full citizenship. This initiative demands an approach integrated by powerful political-institutional components that revert the distorted distribution of opportunities by gender. Men and women have different conditions, situations and needs that must be considered and reflected in public policies (Incháustegui, 1999).

In this sense, public policies must consider the inclusion of the gender approach in all government programs that promote human development. This strategy is known as Gender Mainstreaming ${ }^{4}$. One of the government offices in México that have this mandate is the Ministry of the Environment and Natural Resources (Secretaría de Medio Ambiente y Recursos Naturales, SEMARNAT), through its program of Gender Equality and Environmental Sustainability. Its main objective is: "To institutionalize the gender perspective in the Ministry's public policies and its sector organizations, and to ensure its mainstreaming within the framework of its attributions, so as to guarantee the advancement of women and gender equality in each of the scopes and challenges of the environmental agenda" (SEMARNAT, 2008).

Accordingto Ruiz andLópez(2003), theemergence of this initiative began in México in 1998 with the participation of the Ministry of the Environment, Natural Resources and Fishing (Secretaría de Medio Ambiente, Recursos Naturales y Pesca, (SEMARNAP), the National Women's Commission (Comision Nacional de la Mujer, CONMUJER), and the Red Mujer y Medio Ambiente, which were a detonator that delineated the steps to follow for the adoption of the gender approach in environmental public policies in México. Later, among other things, the following were established: the Declaration for Gender Equity and Action Plan or Work Program for Gender Equity in the SEMARNAP; the creation of a Direction of Gender Equity and the Environment (within the 
Género y el Plan de Acción o Programa de Trabajo de Equidad de Género de la SEMARNAP; la creación de una Dirección de Equidad de Género y Medio Ambiente (dentro de la Unidad Coordinadora de Participación Social y Transparencia) y finalmente el Programa Especial de Equidad de Género, Medio Ambiente y Sustentabilidad (2000-2006) de la SEMARNAT (Secretaría de Medio Ambiente y Recursos Naturales). El programa continuó en el periodo administrativo 2007-2012; finalmente en 2013 aunque con algunos cambios significativos, el proyecto continúa.

Con la adopción de la estrategia de Transversalidad de Género en México, el Programa de Igualdad de la SEMARNAT, es una de tantas iniciativas que se han implementado a nivel institucional. Menciona Aranda (1993) que las mujeres han sido sujeto de muchos programas y acciones implementados a través de diversos planes sectoriales, pero sin un diagnóstico y una política general que planifique y oriente el conjunto de las acciones del sector público hacia la transformación de su situación. En evaluaciones anteriores se ha demostrado que las políticas de género planteadas en México, distan mucho de ser un instrumento que verdaderamente ataque de fondo la situación que viven las mujeres, puesto que se cree que el desarrollo es igual para todos los individuos y se proponen políticas que las afectan negativamente y reproducen los roles de género (Núńez, 2007).

La evaluación de política pública con perspectiva de género cobra importancia, ya que al evaluar los programas desde esta perspectiva se podrán modificar sus estructuras, de tal manera que se identifiquen las diferentes necesidades de ambos sexos, y así se puedan conseguir mejores resultados al otorgar a cada uno lo que realmente necesita, logrando con ello hacer eficiente el uso de los recursos del Estado (Zamudio y Núñez, 2011). La perspectiva de género debe ser incorporada en todo el ciclo del desarrollo de programas, planes y proyectos gubernamentales (planeación, seguimiento y ejercicio presupuestal), a fin de evaluar los posibles efectos que pueden tener estas acciones en los grupos vulnerables y tomar medidas adecuadas para su disminución, siempre tomando en cuenta los diferentes roles, necesidades y responsabilidades de mujeres y hombres. Lo anterior es indispensable, dado que la falta de consideración de la dimensión de género puede ocurrir tanto a la hora de diseñar las políticas como en el momento
Coordinating Unit for Social Participation and Transparency), and finally the Special Program on Gender Equality, the Environment and Sustainability (2000-2006) of the SEMARNAT. The program continued in the administrative period of 20072012; finally in 2013, although with some significant changes, the project continues.

With the adoption of the strategy for Gender Mainstreaming in México, the SEMARNAT Equality Program is one of many initiatives that have been implemented at the institutional level. Aranda (1993) mentions that women have been the subject of many programs and actions implemented through various sectorial plans, although without a diagnosis or general policy to plan and direct the whole of the actions in the public sector aimed at the transformation of their situation. In prior evaluations it has been shown that the gender policies set out in México are far from being an instrument that truly attacks the bottom of the situation that women experience, for there is the belief that development is equal for all individuals and policies are proposed that affect them negatively and reproduce gender roles (Núnez, 2007).

The evaluation of a public policy with gender perspective takes on importance, since after evaluating the programs from this perspective their structures could be modified, so that the different needs of both sexes could be identified, and therefore better results can be obtained when granting each one what they really need, thus managing to make an efficient use of the resources of the State (Zamudio and Núnez, 2011). The gender perspective should be incorporated into the whole development cycle of government programs, plans and projects (planning, follow-up and budget execution), so as to evaluate the possible effects that these actions can have on vulnerable groups and to take the adequate measures for their decrease, always taking into account the different roles, needs and responsibilities of women and men. This is essential, given that the lack of consideration of the gender dimension can happen both at the time of designing the policies and at the time of translating them into a concrete division of resources between the different social needs (Zamudio and Núńez, 2011).

To perform this research study, the following assumptions were established: 1) The incorporation of the gender perspective to the SEMARNAT Equality 
de traducir las mismas en un reparto concreto de los recursos entre las diferentes necesidades sociales $(\mathrm{Za}-$ mudio y Núñez, 2011).

Para la realización del presente trabajo de investigación se plantearon los siguientes supuestos: 1) La incorporación de la perspectiva de género al programa de Igualdad de la SEMARNAT es una estrategia que atiende las demandas prácticas de las mujeres sin integrarlas en el proceso de planeación y aplicación de la política pública; 2) La instrumentación de la perspectiva de género en la Secretaría es un mecanismo que redujo las desigualdades laborales entre mujeres y hombres; 3) El diseño del programa de Igualdad de género con que cuenta la SEMARNAT no contó con la participación de los diferentes actores sociales para proponer, desde cada una de sus perspectivas, las demandas y necesidades sociales.

En este sentido el objetivo general del trabajo fue: Evaluar desde la perspectiva de género la eficiencia y eficacia ${ }^{5}$ en la planeación, seguimiento y ejercicio presupuestal del programa de Igualdad de Género de la SEMARNAT (2008), a través de una metodología de verificación de género en programas sociales. Para ello, se realizó una valoración del grado de incorporación de la perspectiva de género en cada una de las etapas antes mencionadas, una evaluación comparativa y analítica de la estructura laboral vigente de la SEMARNAT, en la Delegación del estado de Michoacán y finalmente se elaboró una propuesta de política ambiental en materia de equidad de género, que incorpore la participación de la sociedad civil, el sector académico y las instituciones involucradas en el tema.

\section{Capítulo Descriptivo y Metodológico}

\section{Programa sujeto de estudio}

En el año 2002, se formuló el programa Equidad de Género, Medio Ambiente y Sustentabilidad, posteriormente en 2007 se integró el Programa Hacia la Igualdad de Género y Sustentabilidad Ambiental 2007-2012, a partir del cual en 2008 se operó un programa de subsidios. Éste programa se operó a través de Lineamientos, con recursos exclusivos para el otorgamiento de apoyos a grupos formados mayormente por mujeres. En 2013 el programa tuvo cambios. Para entonces se fusionaron la Dirección de equidad de género, la
Program is a strategy that addresses the practical demands of women without integrating them into the process of planning and application of the public policy; 2) The implementation of the gender perspective in the Ministry is a mechanism that reduced the labor inequalities between women and men; 3) The design of the Gender Equality Program from SEMARNAT did not have the participation of the different social actors to propose, from each one of their perspectives, the social demands and needs.

In this sense, the general objective of the study was: To evaluate from the gender perspective the efficiency and effectiveness 5 in the planning, followup and budget execution of the SEMARNAT Gender Equality Program (2008), through a methodology of gender verification in social programs. For this purpose, a valuation of the degree of incorporation of the gender perspective in each of the stages mentioned before was carried out, a comparative and analytical evaluation of the current labor structure in SEMARNAT, in the Delegation of the state of Michoacán, and finally, a proposal for environmental policy in matters of gender equity was elaborated, which incorporates the participation of civil society, the academic sector, and the institutions involved in the issue.

\section{Descriptive and Methodological CHAPTER}

\section{Program subject to study}

In 2002, the Gender Equity, Environment and Sustainability Program was formulated; then, in 2007, the Program Aimed at Gender Equality and Environmental Sustainability 2007-2012 was integrated, from which a subsidy program was operated in 2008. This program was operated through Guidelines with resources exclusive for granting supports to groups formed mostly by women. In 2013 the program had changes. By then, the Direction of Gender Equity, the Direction of Indigenous Peoples and the Area for Youth Aimed at Environmental Sustainability were combined, to operate these three with unique Guidelines.

The main objective of the program is: to support groups of women, indigenous people and youth, through subsidies for training or investment for projects for conservation and sustainable exploitation 
Dirección de Pueblos Indígenas y el Área de Jóvenes Hacia la Sustentabilidad Ambiental para operar, las tres anteriores, con Lineamientos únicos.

El objetivo principal del programa es: apoyar a grupos de mujeres, pueblos indígenas y jóvenes, a través de subsidios de capacitación o inversión para proyectos de conservación y aprovechamiento sustentable de los recursos naturales orientados a determinar y revertir el deterioro ambiental y la pérdida de biodiversidad ocasionado por los efectos del cambio climático, así como, desde la perspectiva de género, promover su desarrollo humano y la igualdad de oportunidades entre mujeres y hombres.

Los subsidios se otorgan para operar proyectos de capacitación, inversión o una combinación de ambos:

- Capacitación: apoyo económico destinado al fortalecimiento y desarrollo de las capacidades de las y los beneficiarios, para la administración, gestión y organización de proyectos de conservación, aprovechamiento sustentable y conservación de los recursos naturales. Los gastos relacionados con este concepto son para facilitar la impartición de la capacitación, viáticos y transporte de los técnicos o expertas (os) especializadas (os) en el tema asociado al proyecto.

- Inversión: Apoyo económico destinado a la compra de materiales, herramientas, maquinaria o construcción de infraestructura necesaria para la ejecución del proyecto o para dar continuidad a proyectos que, por sus características, requieran de inversión específica.

Las categorías técnicas de apoyo se agrupan en dos: adaptación, con la que se otorgan proyectos encaminados al manejo integral del agua, conservación y restauración de suelos, y suficiencia alimentaria; y mitigación, principalmente con proyectos relacionados con el consumo eficiente de energía y el tratamiento de residuos sólidos. Así mismo se apoyan proyectos para el fortalecimiento de procesos organizativos y de gestión.

Como complemento y parte de las acciones de capacitación, se lleva a cabo una estrategia de sensibilización sobre derechos humanos, género y masculinidad en el contexto del desarrollo sustentable, dirigida a los grupos de mujeres y pueblos indígenas. Ésta será impartida por una organización de la sociedad civil seleccionada por la SEMARNAT, con base of natural resources directed at determining and reverting the environmental deterioration and the loss of biodiversity caused by the effects of climate change, as well as from the gender perspective, promoting human development and equality of opportunities between women and men.

The subsidies are granted to operate training and investment projects, or a combination of both:

- Training: Economic support allotted for the strengthening and development of the abilities of the men and women beneficiaries, for the administration, management and organization of projects for conservation, sustainable exploitation and conservation of natural resources. The expenses related with this concept are used to facilitate the delivery of training, travel allowances and transport of technicians or experts (men and women) specialized in the issue associated to the project.

- Investment: Economic support allotted for the purchase of materials, tools, machinery or construction of the necessary infrastructure for the project's execution or to give continuity to projects which, because of their characteristics, require specific investment.

The technical categories for support are grouped in two: adaptation, with which projects aimed at the integral management of water, soil conservation and restoration, and food sufficiency, are granted; and mitigation, primarily with projects related to the efficient consumption of energy and the treatment of solid residues. Likewise, projects are supported for the strengthening of organizational and management processes.

As complement and part of the training actions, a strategy for sensitizing on human rights, gender and masculinity within the context of sustainable development was carried out, directed at groups of women and indigenous peoples. This will be imparted by an organization of the civil society selected by the SEMARNAT, based on the publication of an invitation and the performance of a selection process, and judging that will be done by the Coordinating Unit of Social Participation and Transparency (Unidad Coordinadora de Participación Social y Transparencia, UCPAST), based on the Guidelines for the granting of subsidies to organizations of the civil society published in the SEMARNAT webpage. 
en la publicación de una convocatoria y la realización de un proceso de selección y dictaminación que llevará a cabo la Unidad Coordinadora de Participación Social y Transparencia (UCPAST), conforme a los Lineamientos para el otorgamiento de subsidios a organizaciones de la sociedad civil publicados en la página web de la SEMARNAT.

De acuerdo al Programa, el problema que se busca atacar está relacionado con el limitado e inequitativo acceso que tienen las mujeres rurales a: los recursos productivos y tecnológicos, a la disponibilidad de fuentes de financiamiento, a la asesoría técnica y a la capacitación, a la información sobre procesos organizativos y de acercamiento a los programas de desarrollo y, entre otras cosas, a la participación en los órganos de decisión comunitaria y social. Estas limitaciones, aumentan la vulnerabilidad de las mujeres ante la amenaza que representan los efectos ambientales del cambio climático; ya que sus consecuencias, tales como el deterioro ambiental y la pérdida de la biodiversidad, intensifican la problemática social, económica y ambiental.

\section{Metodología de análisis}

La metodología de estudio fue la propuesta por Zamudio y Núñez (2011) para la verificación de Género en Programas Sociales, y cuyo marco referencial es el enfoque de género. De acuerdo con su planteamiento, esta metodología permite verificar si los proyectos y programas sociales cuentan con, o instrumentan la perspectiva de género. Para ello se propone la incorporación de indicadores que permitan identificar si se incluye e integra esta perspectiva en las diferentes etapas.

Para conocer la transversalización de la perspectiva de género en la Secretaría y en el programa de subsidios, se analizaron tres fases: planeación, seguimiento y asignación presupuestal del programa de Igualdad, sobre cuatro aspectos fundamentales del enfoque de género: condición, posición, acceso y control de los recursos. Se realizó un análisis de la perspectiva de género en el programa; un análisis de la estructura laboral y de sueldos en la SEMARNAT Delegación Michoacán, en la que se incluyó además un análisis de la percepción de género en las trabajadoras y los trabajadores. Finalmente con base en un análisis teórico, se concluyó una propuesta de política ambiental con equidad de género para México.
According to the Program, the problem that it seeks to attack is related to the limited and unequal access that rural women have to: productive and technological resources, availability of financing sources, technical counseling and training, information about organizational processes and of approach to development programs and, among other things, to the participation of community and social decision organizations. These limitations increase the vulnerability of women in face of the threat that the environmental effects of climate change represent, since its consequences, such as environmental deterioration and loss of biodiversity, intensify the social, economic and environmental problematic.

\section{Methodology of analysis}

The study methodology was the one proposed by Zamudio and Núñez (2011) for Gender Verification in Social Programs, and whose referential framework is the gender approach. According to their suggestion, this methodology allows verifying whether the social projects and programs have or implement the gender perspective. For this purpose, the incorporation of indicators is proposed that allow identifying whether this perspective includes or is integrated into the different stages.

To understand the mainstreaming of the gender perspective in the Ministry and in the subsidy program, three phases were analyzed: planning, follow-up and budget allotment for the Equality Program, regarding four fundamental aspects of the gender approach: condition, position, access and control of resources. An analysis from the gender perspective in the program was carried out; an analysis of the labor structure and salaries in the SEMARNAT Michoacán Delegation, where in addition an analysis of the gender perception of the women and men workers was included. Finally, based on a theoretical analysis, an environmental policy with gender equity for México was concluded.

To perform the analysis of the gender perspective in the program, a set of indicators that allowed evidencing the changes that the program could generate on the condition and position of women and men, were applied, for each phase mentioned. For this purpose, a matrix for gender verification was built, which is presented in Table 1 . 
Para realizar el análisis de la perspectiva de género en el programa se aplicaron, para cada fase mencionada, un conjunto de indicadores que permitieron evidenciar los cambios que el programa pudo generar sobre la condición y posición de las mujeres y hombres. Para ello se construyó una matriz de verificación de Género, misma que se presenta en el Cuadro 1.

Para responder a las interrogantes planteadas en la Matriz de Verificación de Género, en un primer momento se realizó un análisis documental, que incluyó, entre otras cosas, explorar las siguientes fuentes:

- Lineamientos para el otorgamiento de subsidios a grupos de mujeres, pueblos indígenas y jóvenes, con perspectiva de género, así como Lineamientos de subsidio a Organizaciones de la Sociedad Civil; ambos correspondientes al ejercicio 2013 y publicados en la página electrónica de la SEMARNAT.

- Anexos Técnicos de los Lineamientos, tanto para el subsidio a Grupos como a Organizaciones.

- Anexos respecto a la "Mecánica de Operación de los Lineamientos para el Otorgamiento de Subsidios para Grupos de Mujeres, Pueblos Indígenas y Jóvenes con Perspectiva de Género";

- Listado de Grupos Beneficiarios de proyectos de los subsidios para grupos y Organizaciones, ejercicio 2013.

- Presupuesto de Egresos de la Federación para el ejercicio 2013.

Posteriormente se aplicó una entrevista semiestructurada a un funcionario de la SEMARNAT, con quien se pudo sondear la etapa de diseño del programa. En cuanto al análisis de la estructura laboral y de sueldos, así como la percepción de género de las y los trabajadores de la delegación, se realizó a través de la aplicación de un cuestionario con preguntas semiabiertas y abiertas, que permite recabar información segregada por sexo sobre las características del personal. La encuesta abarcó datos generales como: lugar donde radican, estado civil, nivel de escolaridad y profesión; también se pudo indagar sobre el área, puesto y nivel que ocupan mujeres y hombres dentro de la Secretaría. Otro apartado cuestiona el nivel de acceso a los recursos en mujeres y hombres, sus capacidades y las actividades que realizan, la capacitación que reciben y reconocimientos o estímulos por el trabajo. Finalmente, con el cuestionario se indagó sobre
To respond the questions set out in the Gender Verification Matrix, documentary analysis was carried out during a first moment, which included, among other things, exploring the following sources:

- Guidelines for subsidy granting to groups of women, indigenous peoples and youth, with gender perspective, as well as Guidelines for subsidy to Civil Society Organizations; both corresponded to the 2013 fiscal year and were published in the SEMARNAT web page.

- Technical Appendix of the Guidelines, both for the subsidy to Groups and to Organizations.

- Appendixes about the "Operation Mechanics for the Guidelines for Subsidy Granting for Groups of Women, Indigenous Peoples and Youth with a Gender Perspective";

- List of Groups Benefitted from the subsidy projects for Groups and Organizations, 2013 fiscal year.

- Federal Disbursements Budget for the 2013 fiscal year.

Later a semi-structured interview was applied with a SEMARNAT officer, with whom the stage of program design was probed. As far as the analysis of work and salary structure, as well as the perception of gender of men and women workers of the delegation, it was carried out through the application of a questionnaire with semi-open and open questions, which allows collecting information segregated by sex on the characteristics of the staff. The survey covered general data such as: place of residence, marital status, level of schooling and profession; there were also questions about the area, position and level that women and men occupy within the Ministry. Another section questions the level of access to resources in men and women, their abilities and the activities that they perform, the training they receive and the recognitions or stimuli from work. Finally, with the questionnaire, there were inquiries about possible recognition or demands received from their work performance, as well as in the personal and family spheres.

Finally, the proposal for environmental policy for women was carried out by considering the results obtained, and a theoretical revision was made of some studies that have carried out similar proposals with the aim of comparing information. 


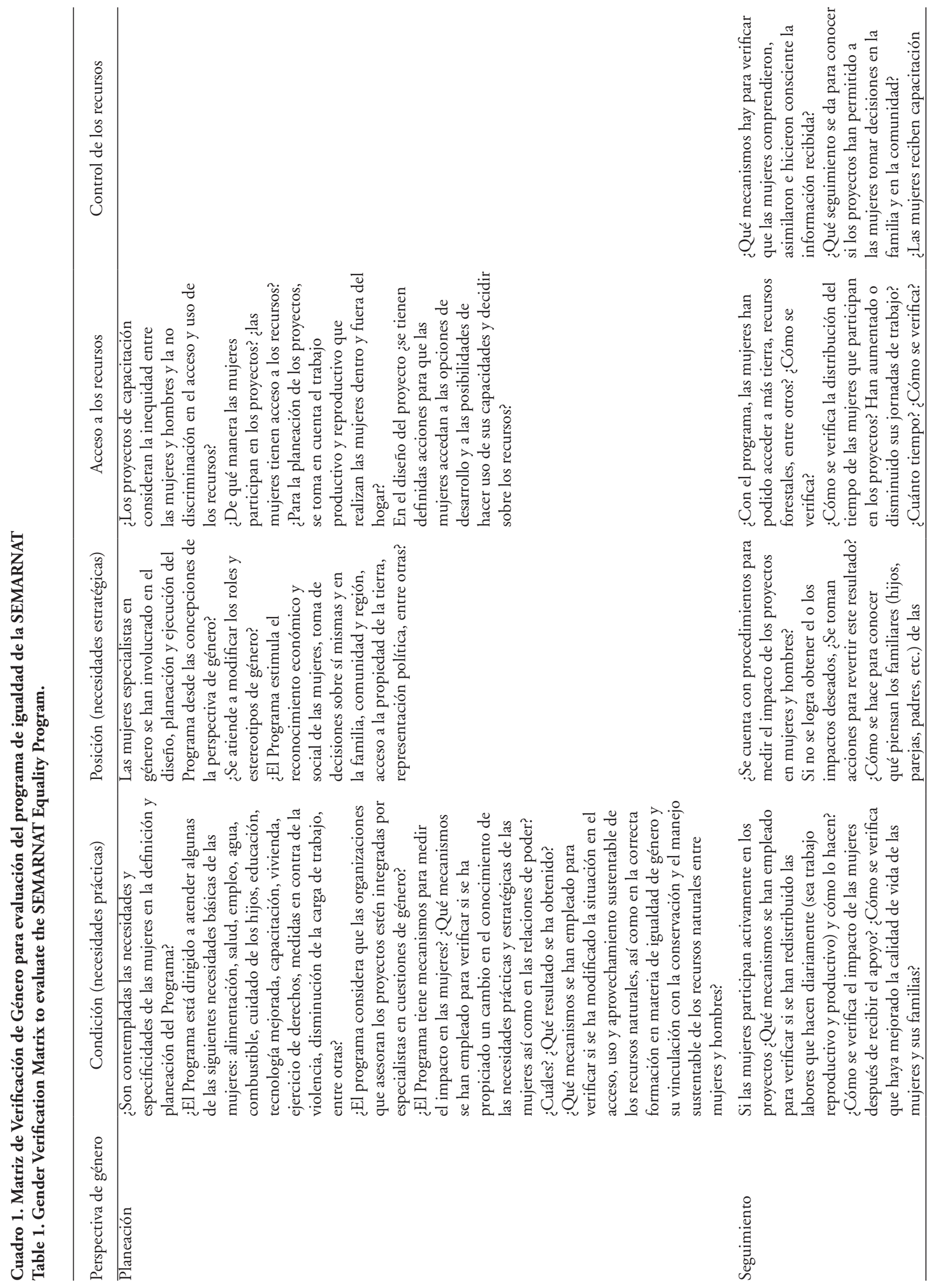




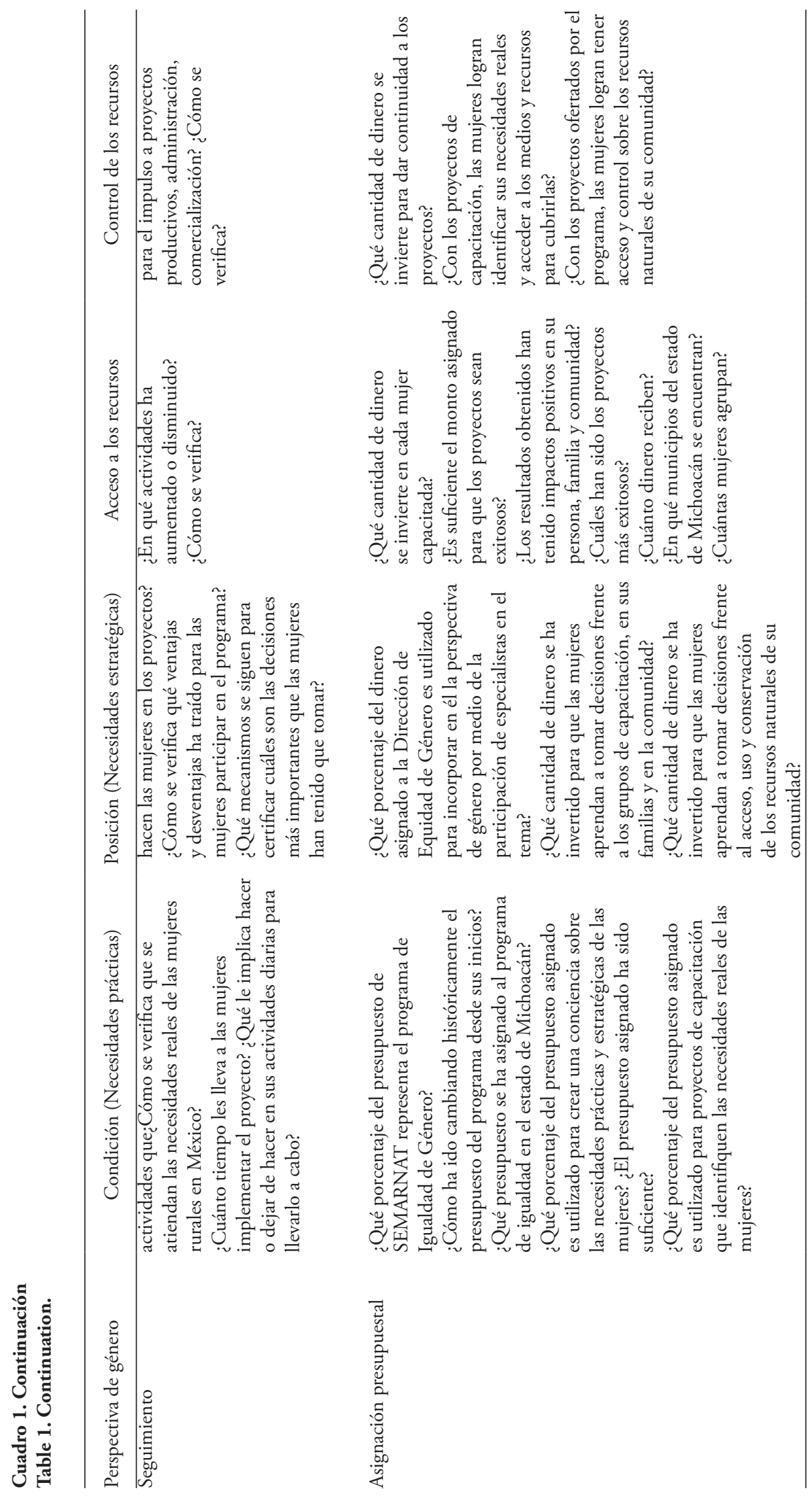


posibles reconocimientos o reclamos recibidos por su desempeño laboral, así como en los ámbitos personal y familiar.

Finalmente, la propuesta de política ambiental para mujeres se realizó considerando los resultados obtenidos, y se hizo una revisión teórica de algunos estudios que han realizado proposiciones similares a fin de cotejar información.

\section{Resultados y Discusión}

\section{Verificación de género en el programa de igualdad de la SEMARNAT para el ejercicio 2013}

En este apartado se presentan textualmente los resultados obtenidos con la Matriz de verificación de Género. Respecto a la etapa de planeación, el análisis cualitativo valoró que no se cuenta con una perspectiva de género, ya que atiende al modelo de Mujeres en el Desarrollo (MED), en el cual se integran a las mujeres a los procesos definidos del sistema económico mundial sin considerar sus necesidades. Es un programa que no considera las necesidades reales de las mujeres y las sigue tratando como si fueran un elemento aislado de la sociedad. Las relaciones sociales son relaciones de género, por lo que no se puede tomar de forma aislada a las mujeres, puesto que viven dentro de una sociedad con tradiciones, estereotipos y roles de género que han sido asignados, y en donde se deben tomar en cuenta las relaciones intra e intergénero para lograr modificaciones en el entorno social que no permitan su segregación, y así lograr una mayor equidad.

La incorporación de la perspectiva de género al Programa de Igualdad de la SEMARNAT, es una estrategia que atiende las demandas prácticas de las mujeres sin integrarlas en el proceso de planeación y aplicación de la política pública. Los programas planteados desde el MED se enfocan en la atención de aquellas necesidades que mujeres y hombres experimentan desde su rol asignado, y que son fruto de responsabilidades cotidianas, como una respuesta a las condiciones materiales inmediatas.

Los principales temas de los proyectos apoyados con el programa tienen que ver con: el consumo eficiente de energía (estufas ahorradoras de leña); el manejo integral del agua (construcción de cisternas de ferro cemento para captación de agua pluvial); la seguridad alimentaria (construcción de huertos

\section{Results AND Discussion}

\section{Gender verification in SEMARNAT's Equality Program for the 2013 fiscal year}

In this section the results obtained with the Gender Verification Matrix are presented verbatim. Regarding the stage of planning, the qualitative analysis assessed that there is not a gender perspective, since it is based on the model of Women in Development (WID), in which women are integrated into the processes defined from the global economic system without considering their needs. It is a program that does not consider the real needs of women and continues to treat them as if they were an isolated element of society. Social relationships are gender relations, so women cannot be considered in an isolated manner, since they live within a society with traditions, stereotypes and gender roles that have been assigned, and where the intra- and inter- gender relationships must be taken into account to achieve modifications in the social environment that do not allow their segregation, and with this attain greater equity.

The incorporation of the gender perspective to the SEMARNAT Equality Program is a strategy that addresses the practical demands of women without integrating them into the process of planning and application of the public policy. The programs set out from the WID are focused on the attention of the needs that women and men experience from their assigned role, and which are fruit of daily responsibilities, as a response to the immediate material conditions.

The main themes of the projects supported by the program have to do with: the efficient consumption of energy (firewood-saving stoves); integral water management (construction of ferrocement tanks for rain water capture); food security (construction of organic vegetable gardens); treatment of solid residues; conservation and restoration of the soil; and strengthening of community organization and management. These actions tend only to practical needs that are not exclusive of women; however, due to the social construction around this, they are identified as women's needs and activities.

An important aspect that was identified was the case of the integration of the groups benefited. The program proposes the participation of women and 
orgánicos); tratamientos de residuos sólidos; conservación y restauración del suelo; y el fortalecimiento a la organización y gestión comunitaria. Estas acciones atienden sólo necesidades prácticas que no son exclusivamente de las mujeres; sin embargo, debido a la construcción social que existe al respecto, se identifican como necesidades y actividades de ellas.

Un aspecto importante que se identificó fue el caso de la integración de los grupos beneficiados. El programa propone la participación de mujeres y hombres para la integración de los grupos; sin embargo, esta acción podría estar sesgando algunos aspectos como el interés, colaboración, intervención, incluso toma de decisiones de las mujeres en el programa, por lo que resulta necesario un estudio en particular respecto a la incidencia de la participación de varones en grupos de mujeres.

En términos ambientales el programa, con su escasa asignación de presupuesto, procura detener y revertir el deterioro de los recursos naturales y la pérdida de la biodiversidad, causados por los efectos del cambio climático, que a su vez, estos se han propiciado con el modelo económico actual; lo anterior a través del desarrollo humano y la igualdad de oportunidades entre mujeres y hombres. En este sentido, se intenta trabajar con las mujeres rurales y las actividades sociales que tienen asignadas con base en roles, a fin de intervenir con proyectos de conservación y protección de los recursos naturales. Sin embargo, aunque se conoce que las mujeres tienen un triple rol (pues ellas realizan labores en el hogar, en el traspatio o incluso en la parcela, labores en la comunidad, y muchas veces también labores productivas o en el trabajo asalariado), el Programa de Igualdad no considera, por ejemplo ¿qué acciones se tomarán para evitar que haya un aumento en las cargas de trabajo?, o ¿qué acciones se tomarán con los varones para que ellos cambien sus esquemas y estereotipos de género? El programa contempla a las mujeres como administradoras eficientes de los recursos y fuente inagotable de trabajo.

Por otro lado, se considera que el programa impone mayores exigencias a las mujeres frente a los nuevos compromisos que adquieren y a los conocimientos que deben tener (en los casos de proyectos con infraestructura), con lo que se les imponen mayores cargas de trabajo, sin cambiar sus condiciones económicas y sociales.

Respecto a la capacitación, el programa destina alrededor de $30 \%$ del recurso total aprobado en este men for the integration of the groups; however, this action could be distorting some aspects like interest, collaboration, intervention, and even decision making of women in the program, which is why a particular study is necessary with regard to the incidence of the participation of men in a group of women.

In environmental terms, the program, with its scarce budget allotment, attempts to stop and revert the deterioration of natural resources and the loss of biodiversity caused by the effects of climate change, which in turn have been fostered by the current economic model; this, through human development and equality of opportunities between women and men. In this sense, there is an attempt to work with rural women and the social activities that they have assigned based on roles, so as to intervene with projects for conservation and protection of natural resources. However, although it is known that women have a triple role (since they carry out household chores, in the backyard or even in the plot, tasks in the community, and many times also have productive tasks or paid work), the Equality Program does not consider, for example, what actions will be taken to avoid an increase of the workload? Or, what actions will be taken with men for them to change their gender schemes and stereotypes? The program contemplates women as efficient administrators of the resources and an inexhaustible source of work.

On the other hand, it is considered that the program imposes greater demands on women in face of new commitments that they acquire and the knowledge that they must have (in the cases of projects with infrastructure), with which higher loads of work are imposed on them, without changing their economic and social conditions.

With regard to training, the program assigns around $30 \%$ of the total resource approved to this area. Through civil society organizations, training projects are brought to the groups benefited, where the following themes are tackled: human rights of women and men; gender (equity, equality and empowering); masculinity (relationship between men and natural resources from their construction of gender and their relationship with power and violence); and sustainable development (access, use, management of natural resources and gender relations); ecological footprint of men and women; environmental, social and economic impacts 
rubro. A través de organizaciones de la sociedad civil, se llevan proyectos de formación a los grupos beneficiados, en los que se tocan los siguientes temas: derechos humanos de mujeres y hombres; género (equidad, igualdad y empoderamiento); masculinidad (relación de los hombres con los recursos naturales a partir de su construcción de género y relación de poder y violencia); y desarrollo sustentable (acceso, uso, manejo de los recursos naturales y las relaciones de género); huella ecológica de hombres y mujeres; Impactos ambientales, sociales y económicos derivados del cambio climático, analizados desde la perspectiva de género). Sin embargo, esta acción no contempla estrategias que impliquen medidas tendientes a que las mujeres campesinas discutan, comprendan y se organicen para transformar el origen y los efectos de la desigualdad sexual.

Otro punto importante es la cuestión del seguimiento y la verificación de los apoyos. Con el análisis realizado a través de la matriz de verificación de género se pudo observar que no existen mecanismos de revisión en campo ni mecanismos de verificación que den cuenta de los impactos sociales que el Programa está presentando. Por ejemplo, ¿qué ventajas o desventajas ha tenido para las mujeres la implementación de los proyectos?, ¿las mujeres están comprendiendo y asimilando la información recibida?, o jen qué medida ha aumentado o disminuido sus cargas de trabajo? Es necesaria la implementación de una etapa de verificación a corto, mediano y largo plazo, que confronte y dé cuenta del avance o empeoramiento en la implementación del programa.

En cuanto a la asignación presupuestal, el Presupuesto de Egresos de la Federación 2013, el Sector Medio Ambiente y Recursos Naturales correspondiente al Ramo Administrativo No.16, tuvo un presupuesto de 56471.2 millones de pesos, de los cuales la SEMARNAT (Sector Central) recibió la cantidad de 5610 millones de pesos. De esta cantidad, al Programa de Igualdad le correspondió apenas $0.6 \%$ equivalente a 35 millones de pesos.

Un análisis histórico de los recursos asignados de 2008 hasta 2014, muestra que la tendencia general durante este periodo fue de aumento. En el primer año el presupuesto asignado fue de $9.7 \mathrm{mi}$ llones de pesos; para 2011 este presupuesto se duplicó y alcanzó los 18.6 millones de pesos; en 2012 y 2013 tuvo nuevamente un aumento significativo con alrededor de 30 millones de pesos; para 2014 la derived from climate change, analyzed from the gender perspective. However, this action does not contemplate strategies that imply measures that tend towards peasant women discussing, understanding and organizing themselves to transform the origin and the effects of sexual inequality.

Another important point is the matter of followup and verification of supports. With the analysis performed through the gender verification matrix, it could be observed that there are no mechanisms for revision in the field, or verification mechanisms that account for the social impacts presented by the Program. For example, what advantages or disadvantages has the implementation of the projects brought for women? Are women understanding and assimilating the information received? Or, to what extent have their workloads increased or decreased? The implementation of a stage for verification in the short, medium and long term is needed, to confront and account for the advancement or worsening in the program's implementation.

Concerning the budget allotment, for the Federal Disbursements Budget 2013, the Environment and Natural Resources Sector corresponds to the Administrative Branch No. 16, and it had a budget of 56471.2 million pesos, of which SEMARNAT (Central Sector) received the amount of 5610 million pesos. Of this, the Equality Program received only $0.6 \%$, equivalent to 35 million pesos.

A historical analysis of the resources allotted from 2008 to 2014 shows that the general trend during this period was to increase. In the first year the budget allotted was 9.7 million pesos; by 2011, this budget was doubled and reached 18.6 million pesos; in 2012 and 2013 it again had a significant increase of around 30 million pesos; for 2014, the trend changed, since the budget attained in prior years presented a drastic fall, practically to half of what it had been in the two prior years, to 14 million pesos.

The proportional amount invested in each member of the group varied considerably, for although it is a fixed amount, the number of participants ranges from 15 to 30 . If we analyze the total resource assigned to women's groups and divide it by the women benefitted, an approximate average is 5 thousand pesos per person. It should be recalled that this resource is not received individually, because it is destined to investment, technical assistance and sensitizing. 
tendencia cambió, puesto que el presupuesto logrado en los años anteriores presenta una caída drástica prácticamente a la mitad de los dos años anteriores, a 14 millones de pesos.

La cantidad proporcional invertida en cada integrante de grupo varía considerablemente, pues aunque es un monto fijo, el número de participantes va entre 15 y 30 . Si hacemos un análisis del recurso total asignado a los grupos de mujeres y lo dividimos entre las mujeres beneficiadas, un promedio aproximado es de 5 mil pesos por persona. Cabe recordar que este recurso no lo reciben individualmente, pues está destinado a inversión, asistencia técnica y sensibilización.

Respecto al presupuesto que se asigna para sensibilización y formación de grupos, del total de presupuesto asignado a través de Lineamientos, tanto para los grupos de mujeres como para Organizaciones de la Sociedad Civil en el ejercicio 2013, alrededor de 9 $\%$ fue asignado para este fin lo que a nivel nacional representa casi 3 millones de pesos.

La cobertura del programa se extiende a los 31 estados de la República Mexicana (Figura 1); atiende ejidos, comunidades, localidades y municipios, preferentemente aquellos que forman parte de los 400 municipios del sistema Nacional para la Cruzada Nacional contra el Hambre $(\mathrm{CNCH})$ (estrategia de
With regard to the budget that is assigned for group sensitizing and training, of the total budget assigned through the Guidelines, both for women's groups and for Civil Society Organizations in the 2013 fiscal year, around $9 \%$ was assigned for that purpose which at the national level represents almost 3 million pesos.

Coverage of the program extends to the 31 states of the Mexican Republic (Figure 1); it supports ejidos, communities, localities and municipalities, preferably those that are part of the 400 municipalities of the national system for the National Crusade against Hunger (Cruzada Nacional contra el Hambre, $\mathrm{CNCH}$ ) (strategy for inclusion and social welfare, which has the purpose of the conservation of natural assets of the general population and the generation of productive opportunities focused on ensuring their access to food, primarily), a list published in the Federation's Official Journal (Diario Oficial de la Federación, DOF) on January 22 ${ }^{\text {nd }}, 2013$. The target population of the program is women and men, indigenous peoples and youth.

The projects with highest demand were those that support activities for family reproduction, which refers to the efficient consumption of energy through the use of firewood-saving stoves (Figure 2). These results exhibit the scarce decrease in gender inequality

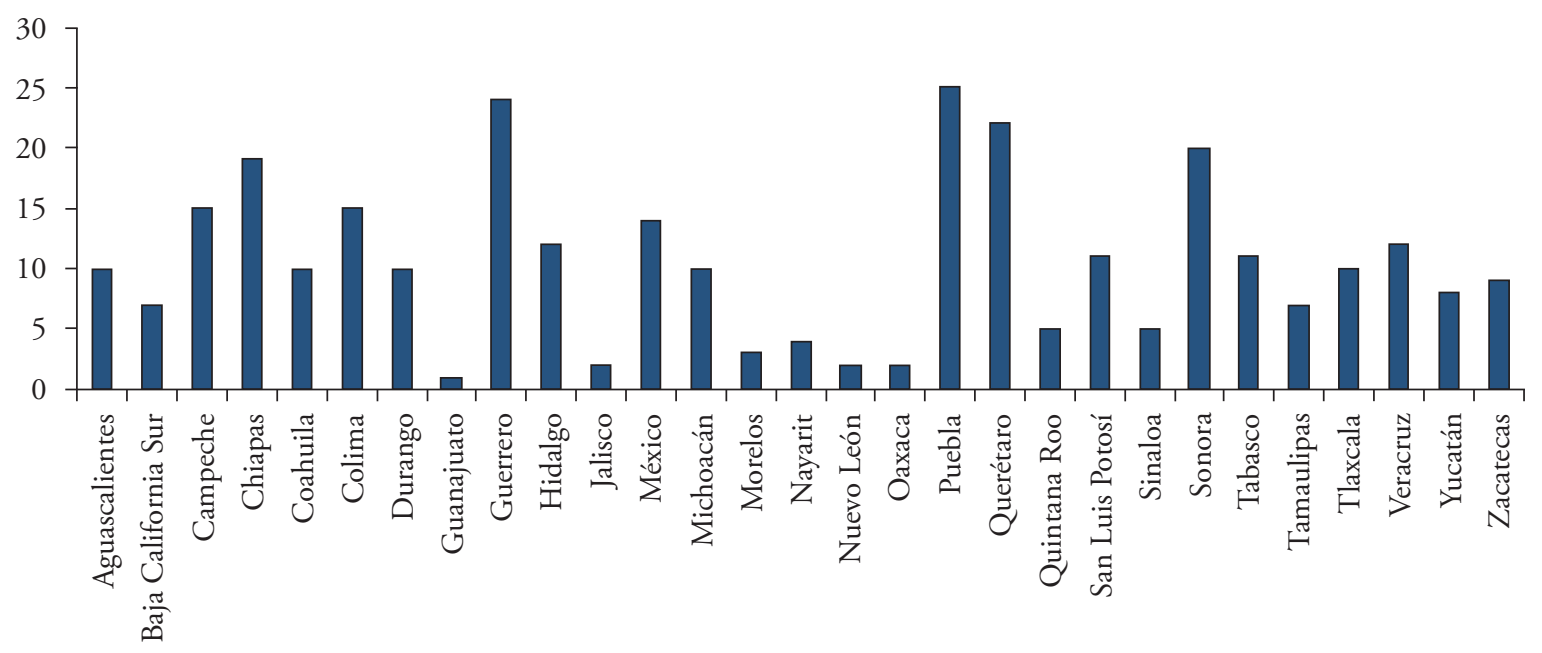

Fuente: elaboración propia a partir de información tomada del Listado de grupos beneficiarios de proyectos de los subsidios para grupos de mujeres, pueblos indígenas y jóvenes, ejercicio 2013. SEMARNAT. Source: authors' elaboration from information taken from the list of groups benefitted from projects with subsidies for groups of women, indigenous peoples and youth, 2013 fiscal year. SEMARNAT.

Figura 1. Distribución de proyectos aprobados por el programa de Igualdad de la SEMARNAT a nivel nacional, para el ejercicio 2013.

Figure 1. Distribution of projects approved by the SEMARNAT Equality Program at the national level, for the 2013 fiscal year. 
inclusión y bienestar social, cuyo propósito es la conservación de los activos naturales de la población en general y la generación de oportunidades productivas enfocadas al aseguramiento de su alimentación, principalmente), listado publicado en el Diario Oficial de la Federación (DOF) el 22 de enero de 2013. La población objetivo del programa son mujeres y hombres, pueblos indígenas y jóvenes.

Los proyectos con mayor demanda fueron aquellos que apoyan actividades para la reproducción familiar, que se refiere al consumo eficiente de energía a través del uso de estufas ahorradoras de leña (Figura 2). Estos resultados exhiben la poca disminución de la desigualdad de género que existe en el medio rural con estos proyectos, ya que como lo menciona Núñez (2007), propicia una destreza mayor de las mujeres en las tareas del ámbito doméstico.

\section{Estructura laboral y de sueldos de trabajadoras (y trabajadores) de la SEMARNAT, Delegación Michoacán, así como percepción de género}

La Delegación de la SEMARNAT en Michoacán está integrada por 32 empleados con puesto de confianza, 10 mujeres y 19 hombres (3 vacantes hasta la fecha de consulta). Considerando la percepción neta de las y los funcionarios en esta Delegación, se hizo una categorización para conocer la composición de género de los puestos con ingreso más bajo a los puestos con ingreso mayor. Se encuentró que $3 \%$ pertenece a la categoría de funcionarios, $53 \%$ a mandos medios, y $44 \%$ a operativos (no se están considerando empleados que tienen un ingreso menor a 7000, y que también son trabajadores operativos de la delegación, debido a que esta información no nos fue proporcionada) (Figura 3).

Los puestos en los que se concentran las mujeres corresponden a los más bajos. Por su parte los varones estan distribuidos en la totalidad de los puestos, incluyendo las coordinaciones y subdelegaciones, donde están los puestos mejor remunerados (Figura 4).

De acuerdo con Zamudio y Núñez (2011), no es raro encontra a las mujeres, dentro de las dependencias gubernamentales, tradicionalmente en puestos de secretarias y asistentes, debido a que son considerados puestos idóneos para ellas por ser buenas administradoras; lo que refleja cómo la dinámica y estructura del ámbito doméstico se reproduce dentro del ámbito público en instituciones, organizaciones, etcétera.

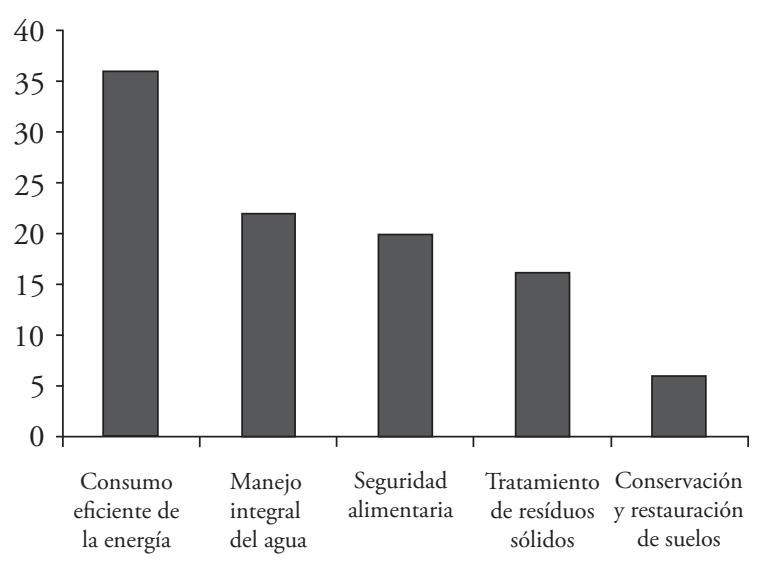

Fuente: elaboración propia a partir de información tomada del Listado de grupos beneficiarios de proyectos de los subsidios para grupos de mujeres, pueblos indígenas y jóvenes, ejercicio 2013, SEMARNAT. Source: author' elaboration from information taken from the list of groups benefitted from projects with subsidies for groups of women, indigenous peoples and youth, 2013 fiscal year. SEMARNAT.

Figura 2. Distribución porcentual de los proyectos aprobados a nivel nacional, según giro. Ejercicio 2013.

Figure 2. Percentage distribution of the projects approved at the national level, according to area. 2013 Fiscal year.

in the rural environment with these projects, since, as Núñez (2007) mentions, they foster a greater skill of women in domestic tasks.

\section{Labor structure and worker's salaries in SEMARNAT, Michoacán Delegation, as well as earnings per gender}

The SEMARNAT Delegation in Michoacán is made up of 32 employees with a position of trust, 10 women and 19 men (3 vacancies until the date of consultation). Considering the net earnings of the women and men officials in this Delegation, a categorization was made to understand the gender composition from the positions with lowest income to the positions with highest income. It was found that $3 \%$ belongs to the category of officials, $53 \%$ to mid-level managers, and $44 \%$ to operative (not considering employees who have an income of less than 7000, and who are also operative workers of the delegation, because this information was not given to us) (Figure 3).

The positions in which the women are concentrated correspond to the lowest. On their part, 


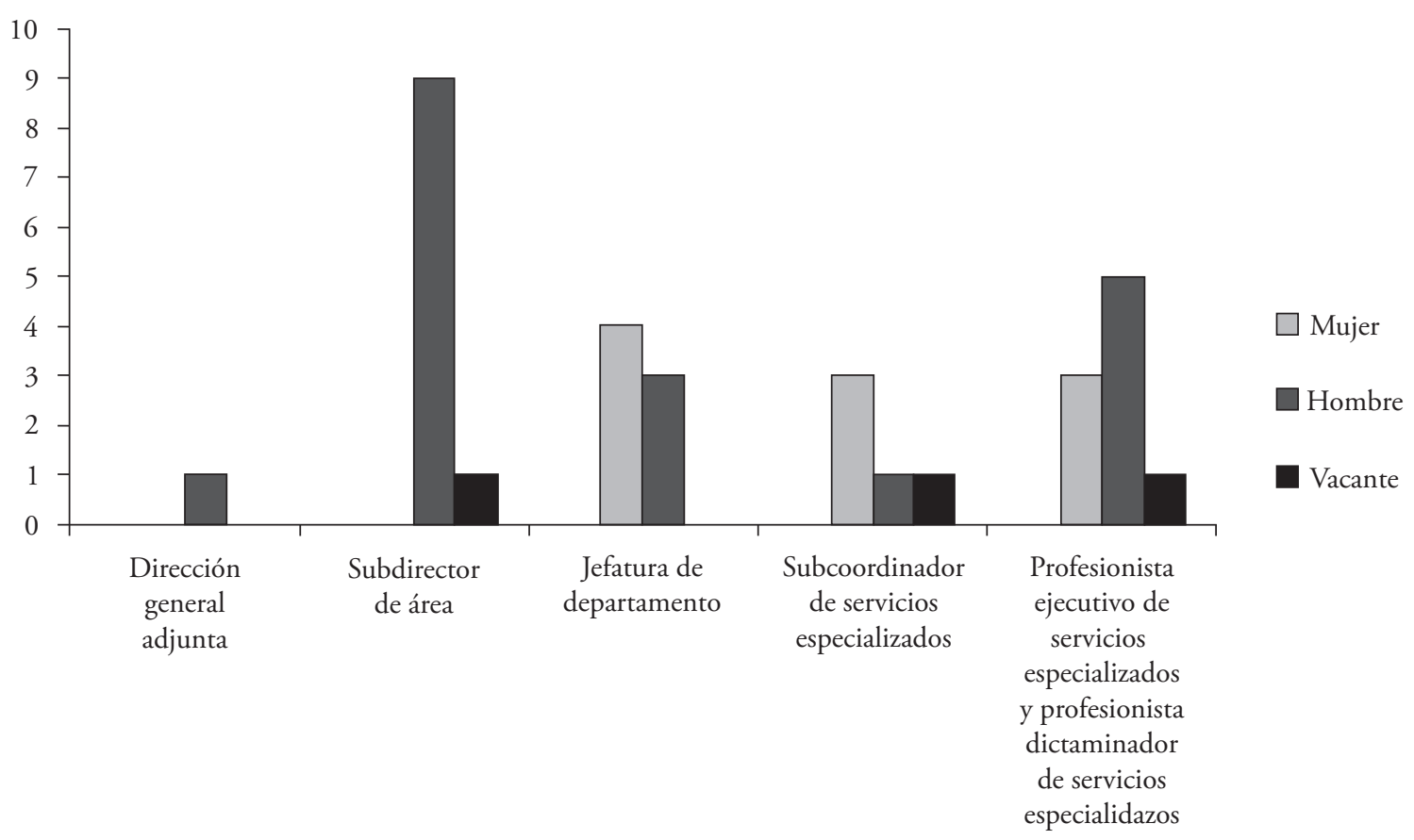

Fuente: elaboración propia con información del Directorio Institucional de la SEMARNAT y la Información disponible en el Portal de Obligaciones de Transparencia del Instituto Federal de Acceso a la Información y Protección de Datos Personales (ifai). \& Source: authors' elaboration with information from the SEMARNAT Institutional Directory and the information available in the Transparency Obligations Portal of the Instituto Federal de Acceso a la Información y Protección de Datos Personales (ifai).

Figura 3. Participación de mujeres y hombres por puesto de trabajo en la Delegación Michoacán de la SEMARNAT, 2014. Figure 3. Participation of women and men per work position in the Michoacán Delegation, SEMARNAT, 2014.

Con respecto a la capacitación con que cuentan o han recibido los empleados de la Delegación, las mujeres entrevistadas refirieron que en su mayoría (6) sí han recibido algún tipo de capacitación y una respondió que no. En cuanto a los varones, el total de los encuestados (13) aseguraron recibir capacitación dentro de la Delegación. Para ambos géneros, los principales temas han sido sobre cuestiones técnicas y de operación, dependiendo de las áreas en las que se desarrollan. Sin embargo reciben en común temas sobre administración, desarrollo personal y temas jurídicos. Así mismo manifestaron que el mayor impacto que han tenido las personas capacitadas ha sido en el ámbito laboral, y en segundo lugar en el ámbito personal.

Para tener una referencia del proceso de sensibilización sobre el tema de género que tiene el personal de la Delegación como parte del proceso de transversalidad, se inquirió sobre las capacitaciones recibidas en este tema. Sorprende el hecho de que en relación a las mujeres, ninguna de ellas declaró haber recibido men are distributed in the totality of the positions, including the coordinations and subdelegations, where the positions that are better paid are found (Figure 4).

According to Zamudio and Núñez (2011), it is not strange to find women within the government offices, traditionally in positions as secretaries and assistants, because these are considered ideal posts for them because they are good administrators; this reflects how the dynamics and the structure of the domestic sphere are reproduced within the public scope in institutions, organizations, etc.

Regarding the training that employees of the Delegation have or have received, the women interviewed described that most of them (6) have received some type of training and one responded that she hadn't. In terms of the men, the total of those surveyed (13) declared having received training within the Delegation. For both genders, the main themes have been about technical and operation issues, depending on the areas where they participate. 


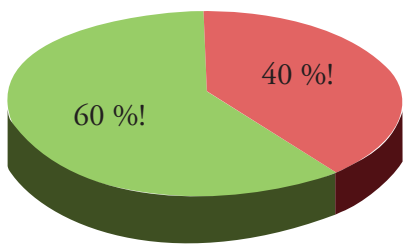

Funcionarias! $\quad$ Medios! $\quad$ Operativos!

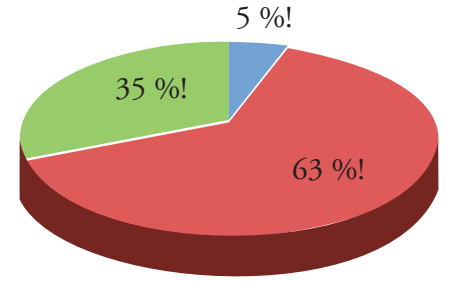

Funcionarias! $\quad$ Medios! Operativos!

Fuente: elaboración propia con información del Directorio Institucional de la SEMARNAT y la Información disponible en el Portal de Obligaciones de Transparencia del Instituto Federal de Acceso a la Información y Protección de Datos Personales (ifai). * Source: authors' elaboration with information from the SEMARNAT Institutional Directory and the information available in the Transparency Obligations Portal from the Instituto Federal de Acceso a la Información y Protección de Datos Personales (ifai).

Figura 4. Distribución porcentual de hombres y mujeres que trabajan en la Delegación Michoacán de la SEMARNAT, según puesto ocupado, 2014.

Figure 4. Percentage distribution of men and women who work in the Michoacán Delegation of SEMARNAT, according to the position occupied, 2014.

capacitación al respecto, mientras que de los varones sólo tres de ellos han recibido al menos una capacitación; dos de ellos son empleados con nivel de jefatura y uno con nivel de Coordinador de área.

Al preguntar al personal encuestado si tenían conocimiento acerca de la perspectiva de género, todas las mujeres y hombres declararon que sí sabían a qué se refería. Algunas respuestas fueron: "Que haya igualdad de oportunidades, de desarrollo y de mejora sin distinción de género", "Considerar que en el desempeño de las funciones que tienen los puestos de trabajo, pueden participar indistintamente mujeres y hombres", "Enfoque con igualdad de derechos entre hombres y mujeres", "Estrategia social, igualdad de oportunidades y responsabilidades", "Es un movimiento que busca que no existan o que terminen las desigualdades de género", "Se refiere a la necesidad de acabar con las desigualdades de trato a mujeres y a sus oportunidades en razón del sexo". Con ello se refleja que el personal tiene un acercamiento a lo que implica la perspectiva de género.

\section{Desafío de las políticas públicas ambientales para México.}

En general, una política pública que pretenda conseguir la igualdad de oportunidades para las mujeres en todos los órdenes, no es posible mientras prevalezca una política económica general que propicia la marginación, la pobreza y el constante deterioro
However, they receive in common themes about administration, personal development and legal issues. Likewise, they manifested that the greatest impact that trained people have had has been in the labor sphere, and in the second place, the personal sphere.

To have a reference of the sensitizing process about the gender issue that staff in the Delegation undergoes as part of the process of mainstreaming, questions were made about the training received on this issue. The fact that none of the women stated having received training about it is surprising, while among the men only three of them have received at least one training; two of them are employees with the level of direction and one with the level of area coordinator.

When asking the staff surveyed if they had knowledge about the gender perspective, all the women and men declared that they did know what this referred to. Some of the answers were: "That there is equality in opportunities, for development and improvement, without gender distinction"; "Considering that in the performance of the functions involved in work positions, men and women can participate indistinctively"; "An approach with equality of rights between men and women"; "Social strategy, equality of opportunities and responsibilities"; "It is a movement that seeks for there not to be or to end gender inequalities"; "It refers to the need to end the inequalities in the treatment of 
de las condiciones de vida (Aranda, 1993). Las mujeres no requieren del diseño de políticas particulares que pretendan resolver los efectos de las desigualdades existentes. Se requiere una política que ataque el origen de la desigualdad económica y genérica, y que reconozca las causas principales de la desigualdad sexual, con la consecuente asignación de recursos que permita una atención planificada y coordinada de sus planteamientos y acciones (Núñez, 2008)

Siguiendo a Núñez, una política integral necesita partir de la premisa fundamental de que las y los sujetos a los que va dirigido son diversos. Aquí es donde cobra relevancia la diferenciación de necesidades y visiones de mujeres y hombres, en la que se desarticulen las causas de la desigualdad entre los sexos.

En el campo de la política ambiental, se sigue suponiendo que en las comunidades hay una homogeneidad de intereses. Joekes et al. (2004) mencionan los signos reveladores que distinguen la política ambiental actual con respecto a la equidad de género: 1) se centra en los roles de sustento de las mujeres; 2) no toman en cuenta la interacción entre papeles femeninos y masculinos; 3 ) ven a las mujeres como administradoras eficientes de los recursos y fuente inagotable de trabajo; 4) suponen que la participación en un proyecto de manejo de recursos naturales por sí mismo beneficiará a las mujeres; y 5) asumen la homogeneidad de intereses entre las mujeres.

En el presente estudio, se encontraron diversas situaciones que coinciden con los aspectos encontrados por Joekes et al. (2004) y que evidencian una planeación errónea de la política, ya que representan un atraso para las mujeres. Considerando nuestro contexto, se plantean los siguientes puntos:

1. La planeación, seguimiento y asignación presupuestal de los programas y proyectos de política pública para mujeres requiere de su participación, involucramiento, y coordinación, tanto con el sector académico como con las organizaciones civiles de mujeres.

2. Quienes generan políticas, y diseñan e implementan las intervenciones del desarrollo, deben asegurarse de que las propuestas no priven a las mujeres del control sobre los recursos, ya sea de modo absoluto o en relación con los hombres.

3. Se deben tener en cuenta los derechos de propiedad de las mujere, ya que esta realidad debe ser comprendida desde el inicio de un proyecto women and their opportunities based on their sex". This reflects that the staff has some understanding of what the gender perspective implies.

\section{Challenge of environmental public policies in México}

In general, a public policy that attempts to attain equal opportunities for women in every area is not possible as long as a general economic policy prevails that promotes marginalization, poverty and the constant deterioration of living conditions (Aranda, 1993). Women do not require the design of specific policies that attempt to solve the effects of existing inequalities. A policy is required that attacks the origin of economic and gender inequality, and which recognizes the main causes of sexual inequality, with the resulting allotment of resources to allow a planned and coordinated attention of their suggestions and actions (Núñez, 2008).

Following Núñez, an integral policy needs to stem from the fundamental premise that the women and men subjects to whom it is being directed are diverse. This is where the differentiation of the needs and visions of women and men takes on relevance, where the causes for inequalities between the sexes are disarticulated.

In the field of environmental policy, it is still being assumed that there is homogeneity of interests in the communities. Joekes et al. (2004) mention the revealing signs that distinguish the current environmental policy with regards to gender equity: 1 ) it is centered on the sustaining roles of women; 2) it does not take into account the interaction between the feminine and masculine roles; 3) it contemplates women as efficient administrators of resources and an inexhaustible source of work; 4) it assumes that participating in a project of natural resources management would benefit women; and 5) it assumes the homogeneity of interests among women.

In this study, various situations were found which agree with the aspects found by Joekes et al. (2004) and which evidence an erroneous planning of the policy, since they represent a setback for women. Considering our context, the following points are suggested:

1. The planning, follow-up and budget allotment of the public policy programs and projects for 
y supervisado activamente durante el desarrollo del mismo. Es fundamental proteger o mejorar el acceso de las mujeres a recursos clave para su vida productiva y reproductiva (tierra y agua).

4. Se debe considerar que los intereses e incentivos de mujeres y hombres en el manejo de los recursos naturales difieren de muchas formas. Si se indaga con las mujeres y los hombres de las comunidades qué entienden por deterioro ambiental o desarrollo sustentable, seguramente las opiniones serán diferentes. Este ejercicio podría ser útil, ya que seguramente también tendrá propuestas de mejora diferentes, y con ello se podrán identificar las diferencias de género en el acceso a los recursos ambientales, y las limitaciones materiales y sociales.

5. Se debe considerar un pago para las mujeres por cualquier contribución laboral que realicen a un proyecto en los mismos términos que a los hombres. Vázquez-García (2011) menciona la necesidad de evitar suponer que la participación de las mujeres en actividades de proyectos es equivalente a obtener beneficios, puesto que pueden existir casos en los que la desviación no remunerada del esfuerzo laboral de las mujeres reduzca su acceso a un ingreso propio. Debe evitarse involucrar a las mujeres en trabajos adicionales a sus obligaciones, si esto les produce un conflicto con sus horas de trabajo.

6. Respecto a la participación, quienes generan las políticas deben prestar particular atención a las relaciones de poder en que se basa la participación, que a menudo muestran una jerarquía de género, y se menosprecian los intereses de las mujeres. Debe asegurarse la representación femenina en todos los espacios (Vázquez-García, 2011). Por su parte Núñez (2008), menciona que las políticas de equidad de género requieren garantizar la participación de las mujeres en el ámbito público, lo que implica la revisión de los marcos legales, a fin de eliminar las desigualdades en el ámbito económico, político y social. Un primer paso es la participación igualitaria de mujeres y hombres en política.

7. Para complementar la política pública, se debe ampliar el espectro de opciones de subsistencia de las personas, especialmente de las mujeres, aunque no necesariamente implique una intervención que abarque actividades del medio ambiente. Mencionan Joekes et al. (2004), que en algunas situaciones el manejo ambiental sustentable y productivo puede lograrse mejor si se asegura la disponibilidad de women require their participation, involvement, and coordination, both with the academic sector and with women's civil organizations.

2. Those that generate policies, and design and implement the development interventions must make sure that the proposals do not deprive women from control over resources, whether absolutely or with regard to men.

3. The property rights of women must be taken into account, since this reality should be understood from the beginning of a project and supervised actively during its development. It is fundamental to protect and improve women's access to key resources for their productive and reproductive lives (land and water).

4. It must be considered that the interests and incentives of women and men in the management of natural resources differ in many ways. If inquiries are made with women and men in the communities about what they understand to be environmental deterioration or sustainable development, surely their opinions will be different. This exercise could be useful, since there will certainly also be different proposals for improvement, and with this the gender differences in access to environmental resources could be identified, as well as the material and social limitations.

5. Payment for women who carry out a project in the same terms as men over any labor contribution should be considered. Vázquez-García (2011) mentions the need to avoid assuming that women's participation in project activities is equivalent to obtaining benefits, since there can be cases where the unpaid deviation of women's labor efforts can reduce their access to an income of their own. Involving women in tasks additional to their obligations should be avoided, if this produces a conflict with their working hours.

6. Concerning participation, those who generate the policies should pay particular attention to the power relations on which the participation is based, which often show a gender hierarchy, and underestimate women's interests. Feminine representation should be ensured in every space (Vázquez-García, 2011). In his turn, Núñez (2008) mentions that gender equity policies require guaranteeing women's participation in the public sphere, which implies the revision of 
empleos e ingresos alternativos, in situ, o en otras partes, para así disminuir la dependencia de las personas de los recursos ambientales.

Algunas acciones adicionales que deben emprenderse en política pública son: reducir la migración masculina hacia el exterior del país, ya que ella obliga a las mujeres a asumir las distintas responsabilidades del núcleo familiar; el problema de la feminización de la pobreza como consecuencia del proceso de globalización; el reconocimiento al trabajo de las mujeres; y la violencia familiar y sexual. La incorporación de las mujeres al mercado de trabajo plantea acciones tendentes a evitar las descalificaciones de las actividades que realizan debido a las desigualdades genéricas. Es fundamental cambiar la concepción del trabajo femenino en una sociedad que las margina y discrimina, el cumplimiento de derechos laborales, apoyo en labores domésticas y necesidades básicas.

\section{Conclusiones}

Después del análisis realizado al Programa de Igualdad de la SEMARNAT, se considera que, aunque tiene algunos elementos sensibles al género, no cuenta con esta perspectiva, ya que es un programa que no considera las necesidades reales de las mujeres. El programa se orienta a generar una mayor destreza de las mujeres en las tareas del ámbito doméstico; no se formulan estrategias que impliquen acciones o medidas tendentes a que las mujeres campesinas discutan, comprendan y se organicen para transformar el origen y los efectos de la desigualdad sexual. Es un programa que aún tiene limitaciones para las condiciones en que viven las mujeres rurales en México. Impone mayores exigencias a las mujeres frente a los nuevos compromisos que adquieren, y a los conocimientos que deben tener.

Respecto al análisis realizado a la estructura laboral y percepción de las y los trabajadores, se concluye que las mujeres se encuentran desfavorecidas tanto en sueldos como en puestos de trabajo, puesto que los varones tienen los mayores salarios y los puestos de trabajo con mayor rango. Adicionalmente, los varones tienen una mayor diversificación en los puestos de trabajo, pudiéndose encontrar tanto en puestos operativos como en altos mandos, mientras que a las mujeres se les encuentra únicamente en puestos de jefatura y operativos. Es un mecanismo que no ha the legal framework, in order to eliminate the inequalities in the economic, political and social scope. A first step is the egalitarian participation of women and men in politics.

7. To complement the public policy, the spectrum of options for subsistence of people must be broadened, especially women's, although this does not necessarily imply an intervention that covers environmental activities. Joekes et al. (2004) mention that in some situations, sustainable and productive environmental management can be achieved better if the availability of jobs and alternative income can be ensured, in situ, or elsewhere, so as to decrease the dependency of people on environmental resources.

Some additional actions that should be undertaken in public policy are: reducing masculine migration towards outside of the country, since it forces women to take on the different responsibilities of the family nucleus; the problem of the feminization of poverty as consequence of the process of globalization; the recognition of women's work; and domestic and sexual violence. The incorporation of women into the labor market suggests actions that tend to avoid the disqualification of activities they perform due to gender inequalities. It is fundamental to change the conception of feminine work in a society that marginalizes and discriminates against women, the compliance to labor rights, support in domestic chores, and basic needs.

\section{Conclusions}

After the analysis carried out with the SEMARNAT Equality Program, it is considered that, although there are some elements sensitive to gender, it does not have this perspective, since it is a program that does not consider the real needs of women. The program is directed at generating a greater skill in women for tasks of the domestic sphere; strategies that imply actions or measures which tend towards women discussing, understanding and organizing themselves to transform the origin and the effects of sexual inequality are not formulated. It is a program that still has limitations for the conditions under which rural women live in México. It imposes greater demands on women in face of the new commitments that they acquire, and of the knowledge that they must have. 
reducido del todo las desigualdades laborales entre mujeres y hombresEl personal que opera en la Delegación ha tenido casi nula capacitación respecto a la perspectiva de género, y quienes han accedido a ella han sido aquellos que operan en los mandos altos. Los encuestados manifestaron tener poco conocimiento respecto a la transversalización de la perspectiva de género y sus conceptos básicos; incluso se les pidió que emitieran sus recomendaciones para que la Secretaría implementara mecanismos para lograr mayor equidad en la Secretaría y mejorar las relaciones laborales. Los resultados reflejan una falta de instrumentación del enfoque de género en esta Delegación, ya que incluso no existe en este nivel un área que opere la estrategia y sus programas.

Aunque a nivel central la Unidad Coordinadora de Participación Social y Transparencia cuenta con una vasta estructura operativa en la que se incluye una Dirección de Equidad de Género, esta organización no se refleja en las Delegaciones Federales de la Secretaría (particularmente en el estado de Michoacán), puesto que no existe un enlace con esta figura que tenga la capacitación y las funciones exclusivas para operar únicamente esta área. Esta problemática tiene que ver con el presupuesto asignado, ya que en México el monto autorizado para los programas que involucran la perspectiva de género es mínimo en relación con el Presupuesto de Egresos de la Federación. Por ello se carece de personal operativo, logística y Reglas específicas de operación.

Aunado al recurso tan limitado y poco significativo del gasto etiquetado para este rubro, es más grave el hecho de que existen pocos análisis, estudios o evaluaciones que den cuenta de la calidad de ese gasto; es decir, hasta dónde efectivamente se incluye la perspectiva de género en las políticas y programas, y hasta dónde ayudan a reducir las desigualdades por género.

El sector ambiental, a través del Programa de Igualdad de Género de la SEMARNAT, tiene un gran reto, ya que la conservación y restauración de los recursos naturales no se logrará únicamente a través de programas y proyectos que se basen en cuestiones técnicas. Para el diseño de una política pública se deben considerar los planes de conservación ambiental, y el ataque a otros problemas sociales que están propiciando este deterioro; entre ellos la pobreza y las desigualdades. Adicionalmente se ha de luchar por los recursos económicos que permitan la aplicación de acciones, así como el involucramiento y coordinación tanto con el
With regard to the analysis carried out of the labor structure and the earnings of women and men workers, it is concluded that women are at a disadvantage both in salaries and in work positions, since the men have higher salaries and work positions with higher rank. In addition, the men have a greater diversification in the work posts, and they can be found both in operative and senior positions, while the women are found only in direction and operative positions. It is a mechanism that has not entirely reduced the labor inequalities between women and men. The staff that operates in the Delegation has had almost no training with regard to gender perspective, and those who have had access to it have been the ones who operate in senior positions. The people surveyed manifested having scarce knowledge about the mainstreaming of the gender perspective and its basic concepts; they were even asked to issue recommendations for the Ministry to implement mechanisms to achieve greater equity in the Ministry and to improve work relations. The results reflect a lack of implementation of the gender approach in this Delegation, since there isn't even an area at this level to operate the strategy and its programs.

Although at the central level the Coordinating Unit for Social Participation and Transparency has a vast operative structure where a Direction for Gender Equity is included, this organization is not reflected in the Ministry's Federal Delegations (particularly in the state of Michoacán), for there is no link with this figure that has the training and exclusive functions to operate solely this area. This problematic has to do with the budget assigned, since in México the amount authorized for the programs that involve the gender perspective is minimum in comparison to the Federation Disbursements Budget. Therefore, there is a lack of operative staff, logistics, and specific rules of operation.

In addition to such a limited resource and insignificant part of the expenditure tagged for this area, the fact that there are few analyses, studies or evaluations that account for the quality of this expenditure is more serious; that is, how far is the gender perspective really included in the policies and programs, and how much does it help to reduce gender inequalities.

The environmental sector, through the SEMARNAT Gender Equality Program has a great challenge, since the conservation and restoration of 
sector académico como con las organizaciones civiles de mujeres, para el planteamiento y diseño de los programas y proyectos.

\section{Notas}

${ }^{4} \mathrm{El}$ término Transversalidad de Género viene del Inglés "Gender mainstreaming", lo que significa cuestionar la corriente principal de las políticas públicas e instalar la cuestión de género en ellas. En 1990 el Consejo de Europa lo definió como la incorporación y aplicación del principio de igualdad de trato y de oportunidades entre mujeres y hombres a las Políticas Públicas, de modo que se garantice el acceso a todos los recursos en igualdad de condiciones, se planifiquen las políticas públicas teniendo en cuenta las desigualdades existentes, y se identifiquen y evalúen los resultados e impactos producidos por éstas en el avance de la igualdad real. * The term "Gender Mainstreaming" means questioning the principal current of public policies and installing the gender issue in them. In 1990, the European Council defined it as the incorporation and application in Public Policies of the principle of equality in treatment and opportunities between men and women, so that access to all the resources is guaranteed under equal conditions, planning of public policies takes into account the existing inequalities, and the results and impacts produced by these in the advancement of actual equality are identified and evaluated.

${ }^{5}$ Entre menor sea la inequidad entre mujeres y hombres, mayor será la eficiencia en el ejercicio de la asignación presupuestal del programa, ya que se podrían aplicar de mejor manera los recursos y se podría obtener el máximo de resultados. Zamudio y Núñez (2011) mencionan que, si los programas son planteados tomando en cuenta las necesidades de mujeres y hombres de manera diferenciada, éstos atenderán de manera más eficaz las prioridades de unas y otros (con un nivel de capacitación más adecuado), y por tanto, el presupuesto ejercido será eficiente. The lower the inequality between men and women is, the higher the efficiency in the execution of budget allotment of the program will be, since the resources could be applied in a better way, and the maximum results could be obtained. Zamudio and Núñez (2011) mention that if the programs are established taking into account the needs of women and men in a differentiated manner, these will address more natural resources will not be achieved only through programs and projects that are based on technical issues. For the design of a public policy, the plans for environmental conservation must be considered, as well as the attack on other social problems that are fostering this deterioration, among them poverty and inequalities. In addition, there should be a struggle over economic resources to allow applying actions, as well as involving and coordinating both with the academic sector and with women's civil organizations, for the suggestion and design of programs and projects.

- End of the English version -

efficiently the priorities of both (with a more adequate level of training), and therefore, the budget executedd will be efficient.

\section{LITERATURA CITADA}

Aranda, Josefina. 1993. Políticas Públicas y mujeres campesinas en México. In: González, S. (coord.). Mujeres y relaciones de género en la antropología latinoamericana. México. El Colegio de México.

Incháustegui, Teresa. 1999. La institucionalización del enfoque de género en las políticas públicas. Apuntes en torno a sus alcances y restricciones. In: Revista de estudios de Género, La Ventana. Num, 10. Guadalajara, México. Consultado el 24 de marzo de 2014 en: http://www.redalyc.org/articulo.oa?id=88411129005.

Incháustegui, Teresa. 2012. ¿Qué es Política Pública con Perspectiva de Género? In: Diplomado Básico en Políticas Públicas y Género. Facultad Latinoamericana de Ciencias Sociales (FLACSO). México. Consultado el 07 de Septiembre de 2014 https:/www.youtube.com/watch?v=HcaY5_CNG58

Joekes, Susan, Cathy Green, y Melissa Leach. 2004. La integración del género en la investigación y las políticas públicas ambientales. In: Verónica Vázquez-García, y Margarita Velázquez (coords). Miradas al futuro. PUEG, UNAM, CRIM, UNAM, COLPOS e IDRC. México.

Núnez, Miriam. 2007. El Enfoque de género: un tema de debate y de política pública para el Desarrollo rural. In: Desarrollo Rural Regional, hoy. Tomo II: Las Políticas Públicas. Universidad Autónoma Chapingo. México, 2007.

Núnez, Miriram. 2008. Desafío de las Políticas Públicas para Mujeres Rurales. En: Economía y Sociedad. Vol.14, Num. 21. México. Consultado el 9 de marzo de 2014 en: http:// www.redalyc.org/pdf/510/51002105.pdf

Ruiz, Dulce, e Isabel López. 2003. Equidad de género, medio ambiente y políticas públicas: el caso de México y la Secretaría de Medio Ambiente y Recursos Naturales. In: Revista de Estudios de Género, La ventana, Num. 17. Guadalajara, México.

SEMARNAT (Secretaría de Medio Ambiente y Recursos Naturales). 2008. Programa: Hacia la Igualdad de Género y la Sustentabilidad Ambiental 2007-2012. México. 
Vázquez-García, Verónica. 2011. Gender Mainstreaming y agua. El programa Nacional Hídrico. In: Revista de Ciencias Sociales, Convergencia. Vol. 18, Num. 56. México, 2011. Consultado el 28 de julio de 2014 en: http://www.redalyc. org/articulo.oa?id=10516855005. pp: 111-132.
Zamudio, Francisco, y Miriam Núńez. 2011. Género, Inequidad y Medición. Universidad Autónoma Chapingo. México. 